\title{
Effect of Oxygen on the Synthesis, Activity and Breakdown of the Rhizobium Denitrification System
}

\author{
By G. W. O'HARA, ${ }^{1}$ R. M. DANIEL ${ }^{1 *}$ AND K. W. STEELE 2 \\ ${ }^{1}$ School of Science, University of Waikato, Hamilton, New Zealand \\ ${ }^{2}$ Ruakura Agricultural Research Centre, Hamilton, New Zealand
}

(Received 3 November 1982; revised 21 March 1983)

\begin{abstract}
The synthesis, activity and breakdown of the denitrifying enzymes of Rhizobium japonicum, $R$. lupini and $R$. meliloti were found to be regulated by $\mathrm{O}_{2}$. Nitrogen oxide reductases were present in anaerobically grown and symbiotic $R$. japonicum, but in the case of organisms that had been grown aerobically the enzymes were induced only after a period of incubation under anaerobic conditions. Activity of the denitrification system that had been induced in aerobically grown cells was inhibited by $\mathrm{O}_{2}$. Denitrification by anaerobically grown cells and bacteroids was stimulated by $5 \% \mathrm{O}_{2}$. Air inhibited denitrification completely. Little loss of denitrifying activity was shown by cells incubated in $5 \% \mathrm{O}_{2}$, but cells incubated at $\geqslant 10 \% \mathrm{O}_{2}$ showed a rapid loss of denitrification activity.
\end{abstract}

\section{INTRODUCTION}

In bacterial respiration the use of ionic and gaseous nitrogen oxides as terminal electron acceptors is usually considered an anaerobic process, and in soils and sediments anaerobic microsites have been invoked to account for denitrification under apparently aerobic conditions (Drew \& Lynch, 1980; Smith, 1980). It has been generally assumed that the nitrogen oxide reductases are repressed by $\mathrm{O}_{2}$ (Knowles, 1982). Derepression of many nitrogen oxide reductases occurs within $40 \mathrm{~min}$ to $3 \mathrm{~h}$ of the removal of $\mathrm{O}_{2}$ (Payne, 1981). However, it has been reported that derepression of dissimilatory nitrate reductase in Pseudomonas aeruginosa occurs at $5 \% \mathrm{O}_{2}$ (Sacks \& Barker, 1949) and that the dissimilatory nitrite reductase in Thiobacillus denitrificans is partially derepressed at $7.8 \% \mathrm{O}_{2}$ (Justin \& Kelly, 1978).

Similar variation has been reported for the effect of $\mathrm{O}_{2}$ on the activity and breakdown of denitrifying enzymes (Payne, 1981). Generally, $\mathrm{O}_{2}$ completely inhibits dissimilatory nitrate reduction (Knowles, 1982), but Betlach \& Tiedje (1981) reported that $10 \% \mathrm{O}_{2}$ did not inhibit the reduction of nitrate to nitrous oxide $\left(\mathrm{N}_{2} \mathrm{O}\right)$ and dinitrogen $\left(\mathrm{N}_{2}\right)$ by Flavobacterium sp. during a $30 \mathrm{~min}$ incubation. Some, but not all, of these disparities may result from inadequate control and measurement of $\mathrm{O}_{2}$ concentrations.

Strains of rhizobia have been shown to possess denitrifying capability both in the free-living (Zablotowicz et al., 1978; Daniel et al., 1980 b, 1982) and symbiotic forms (Zablotowicz \& Focht, 1979). Although denitrification by rhizobia has also been shown to occur in soils (Daniel et al., $1980 a$ ), as yet the conditions affecting the process, and hence its agricultural significance, are not known.

The present study examined the effect of $\mathrm{O}_{2}$ on the synthesis, activity and breakdown of denitrification enzymes in three Rhizobium spp. grown under aerobic, anaerobic, and symbiotic conditions, to determine the conditions under which rhizobial denitrification occurs.

\section{METHODS}

Bacterial strains and growth conditions. Rhizobium japonicum 505 (Wisconsin) was obtained as CC 705 from the Division of Plant Industry, CSIRO, Canberra, Australia. Rhizobium lupini PDD 4681 and $R$. meliloti PDD 2751 were obtained from the Plant Diseases Division, DSIR, Auckland, from Mr P. Bonish, Ruakura Agricultural Research Centre, Hamilton, New Zealand. 
Rhizobia were maintained on yeast extract/mannitol (Daniel \& Appleby, 1972) agar slopes. Inocula were aerobically grown in the same yeast extract/mannitol medium in an orbital shaker at $26{ }^{\circ} \mathrm{C}$.

Preparation of aerobic bacteria. Aerobic cells were grown in $200 \mathrm{ml}$ yeast extract/mannitol medium, with or without $6 \mathrm{mM}-\mathrm{KNO}_{3}$, contained in a 2 litre flask on an orbital shaker $\left(160\right.$ r.p.m.) at $26^{\circ} \mathrm{C}$. Cells were harvested in early-exponential phase $\left(\sim 40 \mu \mathrm{g}\right.$ protein $\left.\mathrm{ml}^{-1}, A_{680} \sim 0 \cdot 3\right)$ by centrifugation $(4800 \mathrm{~g}, 15 \mathrm{~min})$, washed three times in sterile $0 \cdot 1 \mathrm{M}$-sodium phosphate buffer $\left(\mathrm{pH} \mathrm{6.8)}\right.$ and finally resuspended in buffer. The $\mathrm{O}_{2}$ tension during growth was tested on replicate flasks using a Clark oxygen electrode and $\mathrm{O}_{2}$ tension was maintained at $>90 \%$ of air saturation $\left(>230 \mu \mathrm{M}-\mathrm{O}_{2}\right)$.

Preparation of anaerobic bacteria. Anaerobic cells were grown in $15 \mathrm{ml}$ Pyrex conical centrifuge tubes containing $12 \mathrm{ml}$ yeast extract/mannitol medium supplemented with separately sterilized $6 \mathrm{~mm}-\mathrm{KNO}_{3}$ (Daniel et al., 1982). The tubes were sealed with a sterile rubber seal and cultures were grown to late-exponential phase (7-10 d) at $26^{\circ} \mathrm{C}$. The headspace of each tube was tested for the presence of $\mathrm{N}_{2} \mathrm{O}$, and cells were harvested by centrifugation as described above.

Preparation of symbiotic organisms. Bacteroids were isolated and purified from $\mathrm{N}_{2}$-fixing root nodules of: soybean (Glycine max cv. Lincoln) inoculated with $R$. japonicum CC705; lotus (Lotus pedunculatus $\mathrm{cv}$. Marku) inoculated with $R$. lupini PDD 4681; and lucerne (Medicago sativa cv. Wairau) inoculated with $R$. meliloti PDD 2751. Lotus and lucerne seeds were surface-sterilized by soaking in dry $18 \mathrm{M}-\mathrm{H}_{2} \mathrm{SO}_{4}(5 \mathrm{~min})$ followed by repeated washing in sterile distilled water. Soybean seeds were washed in $95 \%$ ethanol $(30 \mathrm{~s})$, soaked in $10 \%(\mathrm{w} / \mathrm{v})$ $\mathrm{NaOCl}(15 \mathrm{~min})$ and washed in sterile distilled water. Seeds were planted directly into quartz sand, previously purified with steam-heated $18 \%(\mathrm{w} / \mathrm{v}) \mathrm{HCl}$ containing $1 \%(\mathrm{w} / \mathrm{v})$ oxalic acid in a 'Keebush' sand-purification unit (Hewitt, 1966) and washed with deionized water. Pots (15 cm diameter) were soaked in $10 \%(\mathrm{w} / \mathrm{v}) \mathrm{NaOCl}$ for $24 \mathrm{~h}$ prior to addition of $1 \mathrm{~kg}$ of sand. Each pot was inoculated with the required Rhizobium strain immediately after planting, and again 2 weeks after emergence of shoots. A $2 \mathrm{~cm}$ layer of wax-coated sand $11 \mathrm{~g}$ paraffin wax ( $\mathrm{kg}$ sand $)^{-1}$ ] was applied to the top of each pot to act as a dust filter. Pots were watered daily to water-holding capacity with a N-free nutrient solution (Smith et al., 1980), the solution being introduced below the wax-coated sand.

Bacteroids were prepared from root nodules by methods used by previous workers (Appleby, 1969; Rigaud et al., 1973; Kennedy et al., 1975). At harvest, roots were removed from pots, shaken free of adhering sand and washed in cold $\left(4^{\circ} \mathrm{C}\right)$ sterile distilled water. Root nodules were rapidly picked off, rinsed in $70 \%$ (v/v) ethanol (30 s), then washed in cold $0 \cdot 1 \mathrm{M}$-sodium phosphate buffer ( $\mathrm{pH} \mathrm{6.8)}$ ) and finally suspended in 3-4 vol. of $\mathrm{N}_{2}$ -

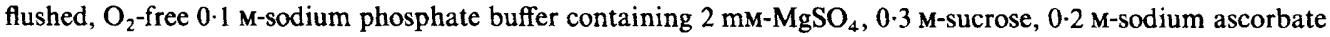
and $10 \%(\mathrm{w} / \mathrm{v})$ polyvinylpyrrolidone. All subsequent manipulations were carried out under $\mathrm{N}_{2}$ at $4{ }^{\circ} \mathrm{C}$ in a glove box. Nodules were disrupted in a sealed Waring blender for $1 \mathrm{~min}$ and the homogenate was twice filtered through Miracloth (Calbiochem) to remove nodule cortex tissue. The filtrate was centrifuged $(200 \mathrm{~g} ; 10 \mathrm{~min})$ to remove starch granules and remaining cortex, then bacteroids were sedimented at $6000 \mathrm{~g}$ for $30 \mathrm{~min}$ and washed twice

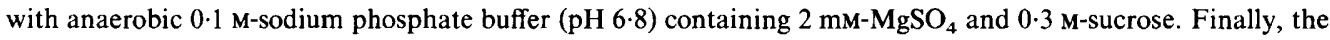
bacteroids were suspended in the same medium in the ratio of $1: 3$ (packed cells/liquid) and used immediately or stored at $-196^{\circ} \mathrm{C}$.

Denitrification reactions. Denitrification by aerobically, anaerobically and symbiotically grown Rhizobium spp. was determined using cell suspensions of $0.1 \mathrm{M}$-sodium phosphate buffer $\left(\mathrm{pH} \mathrm{6.8)} \mathrm{contained} \mathrm{in} \mathrm{a} \mathrm{stirred} \mathrm{O}_{2}\right.$ electrode (Rank Bros, Bottisham, Cambridge) maintained at $24 \pm 0.5^{\circ} \mathrm{C}$. The reaction mixture consisted of $2 \mathrm{ml}$ cell suspension, $6 \mathrm{mM}-\mathrm{KNO}_{3}, 2 \mathrm{mM}$-sodium succinate and $60 \mathrm{~mm}$-glucose in a final volume of $3 \mathrm{ml}$, with a $0.5 \mathrm{ml}$ gas headspace above the suspension. A modified perspex plug for the oxygen electrode was fitted with a $21 \mathrm{G}$ hypodermic needle (Becton-Dickinson Co., N.J., U.S.A.) inserted into the reaction mixture. The dissolved $\mathrm{O}_{2}$ concentration of the reaction mixture was monitored using the electrode and controlled by the supply of $\mathrm{Ar} / \mathrm{O}_{2}$ mixtures being bubbled through the needle into the reaction mixture at about $1.5 \mathrm{ml} \mathrm{min}^{-1}$ using a peristaltic pump (Cole-Palmer, Chicago, U.S.A.). Using standard $\mathrm{N}_{2} \mathrm{O}$ solutions, the equilibration time for the reaction mixture with the gas headspace was shown to be less than $2 \mathrm{~min}$ and with gas mixture flowing through the reaction suspension the half-time for removal of $\mathrm{N}_{2} \mathrm{O}$ from solution was $80 \mathrm{~s}$. Samples of the effluent gas and reaction mixture were analysed for $\mathrm{NO}, \mathrm{N}_{2} \mathrm{O}$ and nitrite. Replicate reactions were run with and without acetylene $\left(\mathrm{C}_{2} \mathrm{H}_{2}\right.$; $10 \%, \mathrm{v} / \mathrm{v})$ in the gas mixture. The synthesis of nitrogen oxide reductases was examined with and without $200 \mu \mathrm{g}$ chloramphenicol ml-1 present in the reaction mixture. Controls were done in the absence of nitrate and also with $\mathrm{N}_{2} \mathrm{O}$ solutions in the absence of bacterial cells.

Other analyses. Nitrite accumulation was estimated as previously described (Daniel et al., 1982).

Gas mixtures were analysed using a Varian 3700 gas chromatograph equipped with a $3 \mathrm{~m} \times 2 \mathrm{~mm}$ stainless steel column containing Porapak Q (80-100 mesh) at $35^{\circ} \mathrm{C}$, with $\mathrm{Ar} / \mathrm{CH}_{4}(95: 5)$ as carrier gas (flow rate $25 \mathrm{ml} \mathrm{min}^{-1}$ ). A ${ }^{63} \mathrm{Ni}$-electron-capture detector at $300^{\circ} \mathrm{C}$ (Kaspar \& Tiedje, 1980) was used to detect very low concentrations of $\mathrm{NO}$ and $\mathrm{N}_{2} \mathrm{O}$. Under the conditions used, the detection limits for a $0.5 \mathrm{ml}$ gas sample were $2 \times 10^{-12} \mathrm{~mol}$ for $\mathrm{N}_{2} \mathrm{O}$ and $2 \times 10^{-11} \mathrm{~mol}$ for $\mathrm{NO}$.

Protein content of whole cells was determined colorimetrically by the procedure of Goa (1953), using bovine serum albumin as the standard. 


\section{RESULTS AND DISCUSSION}

\section{Products of rhizobial denitrification}

No accumulation of nitrite, $\mathrm{NO}$ or $\mathrm{N}_{2} \mathrm{O}$ was detected in cell suspensions incubated in the absence of nitrate, with or without $\mathrm{C}_{2} \mathrm{H}_{2}$ in the inflowing gas. In the presence of nitrate, $R$. japonicum bacteroids accumulated nitrite $\left[60 \mu \mathrm{mol} \mathrm{h}^{-1}(\mathrm{~g} \text { protein })^{-1}\right]$ in the reaction mixture during anaerobic denitrification, but cells grown aerobically or anaerobically did not (Table 1). Both $R$. lupini and $R$. meliloti showed very variable nitrite accumulation.

Low concentrations of NO appeared transiently in denitrifying suspensions of all three species tested, and disappeared from the headspace when all the nitrate and nitrite had been used. In Flavobacterium sp. and Pseudomonas fluorescens this has been taken to show that NO is an intermediate in the denitrification pathway of these organisms (Betlach \& Tiedje, 1981).

Small amounts of $\mathrm{N}_{2} \mathrm{O}$ were produced by $R$. meliloti in the absence of $\mathrm{C}_{2} \mathrm{H}_{2}$. In the presence of $\mathrm{C}_{2} \mathrm{H}_{2}$, however, high concentrations of $\mathrm{N}_{2} \mathrm{O}$ were produced, confirming that $\mathrm{N}_{2}$ is the major end product of denitrification by this strain (Daniel et al., 1982). High levels of $\mathrm{N}_{2} \mathrm{O}$ were produced by $R$. japonicum and $R$. lupini, with no significant increase in $\mathrm{N}_{2} \mathrm{O}$ concentration when $\mathrm{C}_{2} \mathrm{H}_{2}$ was present, confirming $\mathrm{N}_{2} \mathrm{O}$ as the major end product of these strains (Daniel et al., 1982). Rhizobium japonicum was the most active denitrifier under the growth conditions used in the present study.

\section{Effect of oxygen on the synthesis of the rhizobial denitrification system}

Anaerobic and symbiotic $R$. japonicum cells were capable of immediate denitrification and the presence of the protein synthesis inhibitor chloramphenicol did not affect denitrification. However, aerobically grown cells required approximately $60 \mathrm{~min}$ anaerobic incubation before denitrification would occur, and these cells did not denitrify if chloramphenicol was present during this incubation. If any $\mathrm{O}_{2}$ was present $\left(>0.26 \mu \mathrm{M}-\mathrm{O}_{2}\right)$ during this incubation, no denitrification occurred. The presence or absence of nitrate had no effect on the synthesis of these enzymes. This $60 \mathrm{~min}$ anaerobic incubation period is similar to the time lag necessary for the induction of denitrifying enzymes in other organisms (Payne, 1981; Knowles, 1982). Nitrite accumulated at a rate of about $1 \mu \mathrm{mol} \mathrm{min}^{-1}(\mathrm{~g} \text { protein })^{-1}$ in anaerobic suspensions of aerobically grown cells containing $200 \mu \mathrm{g}$ chloramphenicol ml $\mathrm{m}^{-1}$, showing the presence of a nitrate reductase in aerobically grown $R$. japonicum. The $60 \mathrm{~min}$ delay before detection of $\mathrm{N}_{2} \mathrm{O}$ was presumably necessary for the synthesis of nitrite reductase and possibly NO reductase.

The reduction of nitrate to $\mathrm{N}_{2} \mathrm{O}$ by $R$. japonicum and $R$. lupini bacteroids and to $\mathrm{N}_{2}$ by $R$. meliloti bacteroids demonstrates the existence of complete denitrification systems in rhizobia grown symbiotically in the absence of external combined nitrogen. The presence of nitrate reductase activity in bacteroids isolated from legume nodules grown without combined nitrogen is well established (e.g. Cheniae \& Evans, 1960; Daniel \& Appleby, 1972; Kennedy et al., 1975). Our results show that synthesis of denitrification enzymes in the three Rhizobium spp. examined is not controlled by nitrate but by $\mathrm{O}_{2}$ tension, as was found by Daniel \& Gray (1976) for nitrate reductase in $R$. japonicum. Furthermore, activities of nitrogen oxide reductases were similar in anaerobically grown cells and in bacteroids, presumably because the $\mathrm{O}_{2}$ concentration within the root nodule is very low ( $\simeq 11 \mathrm{nM}$; Appleby, 1974).

\section{Effect of oxygen on rhizobium denitrification activity}

Denitrification activity in the three Rhizobium spp. tested was controlled by the oxygen concentration in the reaction mixture (Table 2). Aerobic rhizobia did not denitrify in the presence of $\mathrm{O}_{2}$, whereas the rate of denitrification was faster at $5 \% \mathrm{O}_{2}$ than at $0 \% \mathrm{O}_{2}$ for cells grown anaerobically and symbiotically. No activity was shown by cells incubated above $8 \% \mathrm{O}_{2}$. When the $\mathrm{O}_{2}$ tension was shifted between $0 \%, 5 \%$ and above $8 \% \mathrm{O}_{2}$, in the same cell suspension, the change in denitrification rate was immediate and reversible. The enhanced rates of $\mathrm{N}_{2} \mathrm{O}$ production at $5 \% \mathrm{O}_{2}$ were observed to continue for $>2 \mathrm{~h}$.

A possible increase in nitrate and nitrite reduction by Rhizobium spp. cultured under microaerobic conditions, as compared with anaerobic cultures, was suggested by the results of 


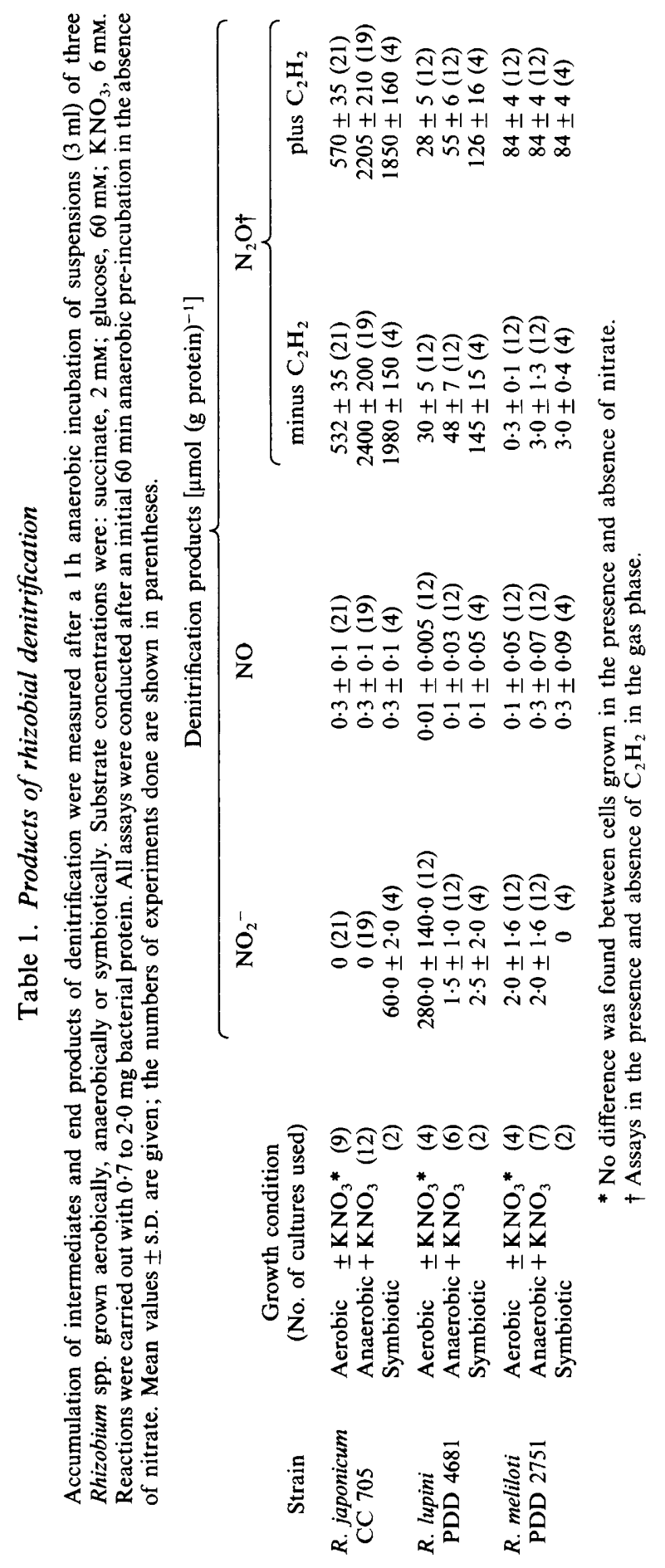




\section{Table 2. Effects of oxygen on the rate of rhizobial denitrification}

Effects of oxygen on the denitrification rate were determined for three Rhizobium spp. grown aerobically, anaerobically or symbiotically. Substrate concentrations were: succinate, $2 \mathrm{~mm}$; glucose, $60 \mathrm{~mm}$; $\mathrm{KNO}_{3}, 6 \mathrm{~mm}$. Reactions were carried out with 0.7 to $2.0 \mathrm{mg}$ bacterial protein. All assays were conducted after an initial $60 \mathrm{~min}$ anaerobic pre-incubation in the absence of nitrate. Mean values \pm S.D. are given; the numbers of experiments done are shown in parentheses. No $\mathrm{N}_{2} \mathrm{O}$ was produced by any of the preparations when the gas phase was air.

\begin{tabular}{|c|c|c|c|}
\hline \multirow{3}{*}{$\begin{array}{l}\text { Strain } \\
R . \text { japonicum } \\
\text { CC } 705\end{array}$} & \multirow{3}{*}{$\begin{array}{l}\text { Growth condition } \\
\text { (No. of cultures used) } \\
\text { Aerobic } \pm \mathrm{KNO}_{3}^{*} \\
\text { Anaerobic }+\mathrm{KNO}_{3} \\
\text { Symbiotic }\end{array}$} & \multicolumn{2}{|c|}{$\begin{array}{c}\text { Denitrification rate }\left[\mu \mathrm{mol} \mathrm{N}_{2} \mathrm{O} \min ^{-1}\left(\mathrm{~g}_{\text {protein }}\right)^{-1}\right] \\
\text { with gas phase: }\end{array}$} \\
\hline & & $0 \% \mathrm{O}_{2}$ & $5 \% \mathrm{O}_{2}$ \\
\hline & & $\begin{array}{l}23 \cdot 0 \pm 4 \cdot 1(21) \\
40 \cdot 0 \pm 5 \cdot 2(19) \\
33 \cdot 0 \pm 4 \cdot 4\end{array}$ & $\begin{array}{c}0 \\
80 \cdot 0 \pm 6 \cdot 5(19) \\
75 \cdot 0 \pm 7 \cdot 5\end{array}$ \\
\hline $\begin{array}{l}\text { R. lupini } \\
\text { PDD } 4681\end{array}$ & $\begin{array}{ll}\text { Aerobic } \pm \mathrm{KNO}_{3}^{*} & (4) \\
\text { Anaerobic }+\mathrm{KNO}_{3} & (6) \\
\text { Symbiotic } & (2)\end{array}$ & $\begin{array}{l}0 \cdot 5 \pm 0 \cdot 3(12) \\
0 \cdot 8 \pm 0.5(12) \\
2 \cdot 1 \pm 0.5 \quad(4)\end{array}$ & $\begin{array}{c}0 \\
2 \cdot 6 \pm 0 \cdot 7(12) \\
11 \cdot 3 \pm 1 \cdot 4\end{array}$ \\
\hline $\begin{array}{l}\text { R. meliloti } † \\
\text { PDD2751 }\end{array}$ & $\begin{array}{ll}\text { Aerobic } \pm \mathrm{KNO}_{3}{ }^{*} & (4) \\
\text { Anaerobic }+\mathrm{KNO}_{3} & (7) \\
\text { Symbiotic } & (2)\end{array}$ & $\begin{array}{l}5 \cdot 7 \pm 1 \cdot 3(12) \\
6 \cdot 2 \pm 1 \cdot 2(12) \\
7 \cdot 3 \pm 1 \cdot 7\end{array}$ & $\begin{array}{c}0 \quad(12) \\
10 \cdot 5 \pm 2 \cdot 6(12) \\
13 \cdot 2 \pm 1 \cdot 2 \quad(4)\end{array}$ \\
\hline
\end{tabular}

Murphy \& Elkan (1965), and Picci \& Lepidi (1967). Increasing aeration of $R$. japonicum cultures increased nitrate reduction, and, using a mass spectrophotometer, the products of nitrate reduction were suggested to be nitrite, $\mathrm{N}_{2} \mathrm{O}$ and possibly $\mathrm{NO}$ and $\mathrm{N}_{2}$ (Murphy \& Elkan, 1965). However, in these earlier studies the $\mathrm{O}_{2}$ tension of the culture medium during growth was not measured or controlled.

\section{Effect of oxygen on the breakdown of rhizobium denitrification enzymes}

Denitrifying cells of $R$. japonicum incubated for $48 \mathrm{~h}$ in $\mathrm{O}_{2}$ concentrations of $0 \%, 3 \%$ and $5 \%$ showed little loss of denitrification activity when assayed under anaerobic conditions. However, cells incubated at $\geqslant 10 \% \mathrm{O}_{2}$ showed an irreversible loss of anaerobic denitrification activity, with more than half of the activity being lost after $1 \mathrm{~h}$ incubation. Thus $\mathrm{O}_{2}$ affects the stability of rhizobial denitrification enzymes as well as their activity.

\section{Ecological considerations}

Denitrification allows rhizobia to survive and grow under anaerobic conditions (e.g. Zablotowicz et al., 1978; Daniel et al., 1980b). Furthermore, since nitrate and nitrite ions in the soil are known to inhibit the infection and nodule development stages of the Rhizobium-legume symbiosis (Dart, 1977; Gibson, 1977; Dazzo \& Brill, 1978), it might well be of selective advantage to free-living rhizobia if inhibitory concentrations of nitrate and nitrite were removed from the rhizosphere by denitrification. Although the assimilation of such soil nitrate would seem to be a much 'cheaper' process than establishment of a symbiosis for $\mathbf{N}_{2}$ fixation, the latter may be of greater long term benefit to rhizobia.

The advantage of rhizobial denitrification within the root nodule is less clear. Although rhizobial denitrification may remove the nitrogen oxides which also adversely affect $\mathrm{N}_{2}$ fixation (Pate, 1977; Burris, 1979; Trinchant \& Rigaud, 1981, 1982) it is not obvious how this removal benefits the bacteria or the plant, since the energetic cost of assimilating nitrogen by $\mathrm{N}_{2}$ fixation is large compared with nitrate assimilation. The reduction of nitrate to $\mathrm{N}_{2} \mathrm{O}$ by $R$. japonicum (Daniel et al., 1980b) and the assimilation of ${ }^{15} \mathrm{~N}_{2} \mathrm{O}$ by soybean bacteroids via nitrogenase action (Mozen \& Burris, 1954) suggest that nitrate may be incorporated via this pathway, but at a considerable cost in energy. Indeed, the assimilation of ${ }^{15} \mathrm{NO}_{3}$ by pea, soybean and lucerne root nodules (Pate, 1977; Randall et al., 1978; Ohyama \& Kumazawa, 1979; Vance \& Heichel, 
1981) may occur by this process, as it does in the photosynthetic, denitrifying, nitrogen-fixing bacterium, Rhodopseudomonas sphaeroides (Dunstan et al., 1982). Under these conditions the bacteroids could be considered to be parasitic on the host legume because they provide a nitrogen assimilation system which is more energy expensive than that involving plant enzymes alone. However, the total amount of plant nitrogen derived from reduction of nitrate in root nodules is considered to be small (Vance \& Heichel, 1981) and it is not known how much, if any, nitrogen is lost as $\mathrm{N}_{2} \mathrm{O}$ and $\mathrm{N}_{2}$. Further studies using ${ }^{15} \mathrm{~N}$-labelled compounds will be necessary to determine whether significant losses of nitrogen occur through bacteroid denitrification.

Since the concentration of $\mathrm{O}_{2}$ is low in root nodules, the control of rhizobial denitrification by $\mathrm{O}_{2}$ observed in the present study probably does not actually occur in functional bacteroids. It is more likely to be important in free-living rhizobia in the rhizosphere, in immature and senescing bacteroids in root nodules, and in senescent root nodules when rapid use of available energy sources may be advantageous for survival. The rationale for the control by $\mathrm{O}_{2}$ of the induction and breakdown of the denitrification system for rhizobia therefore seems straightforward. However, the advantage to anaerobic and symbiotic cells of an increasing denitrification rate up to an $\mathrm{O}_{2}$ tension of $5 \%$ is not clear. Respiration is fully active in $R$. japonicum at this $\mathrm{O}_{2}$ tension in the presence of nitrate (R. M. Daniel, unpublished observations), so that the use of nitrate as an electron acceptor is inefficient, since less energy is generated per mol of substrate consumed (Daniel et al., 1980b). Perhaps the capacity to simultaneously respire to $\mathrm{O}_{2}$ and nitrate is an advantage when excess carbon source is available, such as might occur during plant or nodule senescence.

Some of the uncertainties concerning the effect of nitrate reductase on symbiotic efficiency (e.g. Cheniae \& Evans, 1960; Bergersen, 1961 ; Antoun et al., 1980; Vasconcelos et al., 1980) may have arisen because of the presence of other denitrification enzymes. To date, most reports of the synthesis and accumulation of nitrite in legume nodules, and the interaction of nitrate reductase and nitrogenase, have not included consideration of the influence of the other nitrogen oxide reductases, (e.g. Sik et al., 1976; Gibson \& Pagan, 1977; Manhart \& Wong, 1980; Streeter, 1982).

The current concept of anaerobic micro-environments invoked to explain denitrification in aerobic soils (Drew \& Lynch, 1980) is based largely on $\mathrm{O}_{2}$ flux calculations (Smith, 1980), and the production of $\mathrm{N}_{2} \mathrm{O}$ or $\mathrm{H}_{2} \mathrm{~S}$, which are usually associated with anoxic conditions (Paul \& Victoria, 1978). However, there have been few direct measurements to test models of anaerobic zones in soils (Smith, 1980), and the present results demonstrate that significant denitrification by rhizobia may occur in aerobic as well as anaerobic microsites in the soil after quite short exposures to anaerobic conditions. The bulk of soil in land use for most agricultural crops is aerobic or micro-aerobic (Drew \& Lynch, 1980), and the results here, together with those of Daniel et al. (1980a), show that rhizobial denitrification may occur and persist in the rhizosphere, even under conditions where $\mathrm{O}_{2}$ is present. Until information is available on rhizobia grown at $\mathrm{O}_{2}$ tensions approximating those found in soils, it is difficult to comment on the significance for agricultural systems of the $\mathrm{O}_{2}$ control of denitrification shown here.

The denitrification system in rhizobia has two potential functions. The reduction of nitrate to nitrite yields energy and enables anaerobic growth (Daniel \& Appleby, 1972; Daniel et al., $1980 \mathrm{~b}$ ), and possibly enhanced survival under anaerobic conditions. Denitrification also has a detoxification role since nitrate and nitrite prevent nodulation and inhibit nitrogen fixation. This study has shown both these functions of the denitrification system are dependent on $\mathrm{O}_{2}$.

We acknowledge financial support from the Ministry of Agriculture and Fisheries. We thank Mr P. Bonish of M. A. F. Ruakura Research Centre for the supply of rhizobium strains, Mr P. de Nicolo for technical assistance and $\operatorname{Dr}$ A. B. Cooper for helpful discussions.

\section{REFERENCES}

Antoun, H., Bordeleau, L. M., Prevost, D. \& LACHANCE, R. A. (1980). Absence of a correlation between nitrate reductase and symbiotic nitrogen fixation efficiency in Rhizobium meliloti. Canadian Journal of Plant Science 60, 209-212.
APPLEBY, C. A. (1969). Electron transport systems of Rhizobium japonicum I. Haemoprotein P-450, other $\mathrm{CO}$-reactive pigments, cytochromes and oxidases in bacteroids from $\mathrm{N}_{2}$-fixing root nodules. Biochimica et biophysica acta 172, 71-87. 
APpleby, C. A. (1974). Leghemoglobin. In The Biology of Nitrogen Fixation, pp. 521-554. Edited by A. Quispel. Amsterdam: North Holland Publishing Co.

BERGERSEN, F. J. (1961). Nitrate reductase in soybean root nodules. Biochimica et biophysica acta 52, 206207.

Betlach, M. R. \& Tiedje, J. M. (1981). Kinetic explanation for accumulation of nitrite, nitric oxide and nitrous oxide during bacterial denitrification. Applied and Environmental Microbiology 42, 1074 1084.

Burris, R. J. (1979). Inhibition. In $A$ Treatise on Dinitrogen Fixation, Section II Biochemistry, pp. 569 604. Edited by R. W. F. Hardy \& R. C. Burns. New York: John Wiley.

Cheniae, G. \& Evans, H. J. (1960). Physiological studies on nodule-nitrate reductase. Plant Physiology 35, 454-462.

Daniel, R. M. \& Appleby, C. A. (1972). Anaerobicnitrate, symbiotic and aerobic growth of Rhizobium japonicum: effects on cytochrome P-450, other haemoproteins, nitrate and nitrite reductases. Biochimica et biophysica acta 275, 347-354.

Daniel, R. M. \& Gray, J. (1976). Nitrate reductase from anaerobically grown Rhizobium japonicum. Journal of General Microbiology 96, 247-251.

Daniel, R. M., Steele, K. W. \& Limmer, A. W. $(1980 a)$. Denitrification by rhizobia. A possible factor contributing to nitrogen losses from soils. New Zealand Agricultural Science 14, 109-112.

Daniel, R. M., Smith, I. M., Phillip, J. A. D., Ratcliffe, H. D., Drozd, J. W. \& Bull, A. T. $(1980 b)$. Anaerobic growth and denitrification by Rhizobium japonicum and other rhizobia. Journal of General Microbiology 120, 157-521.

Daniel, R. M., Limmer, A. W., Steele, K. W. \& SMITH, I. M. (1982). Anaerobic growth, nitrate reduction and denitrification in 46 rhizobium strains. Journal of General Microbiology 128, $1811-$ 1815.

DART, P. (1977). Infection and development of leguminous nodules. In $A$ Treatise on Dinitrogen Fixation, Section 3, Biology, pp. 367-472. Edited by R. W. F. Hardy \& W. S. Silver. New York: John Wiley.

DAZzo, F. B. \& BRILL, W. J. (1978). Regulation by fixed nitrogen of host-symbiont recognition in the Rhizobium - clover symbiosis. Plant Physiology 62, 18-21.

DREW, M. C. \& LYNCH, J. M. (1980). Soil anaerobiosis, microorganisms and root function. Annual Review of Phytopathology 18, 37-66.

Dunstan, R. J., Kelley, B. C. \& Nicholas, D. J. D. (1982). The recycling of $\mathrm{N}_{2}$ and $\mathrm{H}_{2}$ in a denitrifying phototrophic bacterium. 12th International Congress of Biochemistry, Perth, Western Australia, p. 154 (abstract).

Gibson, A. H. (1977). The influence of the environment and managerial practices on the legumeRhizobium symbiosis. In $A$ Treatise on Dinitrogen Fixation, Section 4, Agronomy and Ecology, pp. 393450. Edited by R. W. F. Hardy \& A. H. Gibson. New York: John Wiley.

Gibson, A. H. \& Pagan, J. D. (1977). Nitrate effects on the nodulation of legumes inoculated with nitratereductase-deficient mutants of Rhizobium. Planta 134, 17-22.
GoA, J. (1953). A micro biuret method for protein determination. Determination of total protein in cerebrospinal fluid. Scandinavian Journal of Clinical and Laboratory Investigations 5, 218-222.

HEwIT, E. J. (1966). Sand and Water Culture Methods Used in the Study of Plant Nutrition. Farnham Royal, (Bucks): Commonwealth Agricultural Bureaux.

Justin, P. \& Kelly, D. P. (1978). Metabolic changes in Thiobacillus denitrificans accompanying the transition from aerobic to anaerobic growth in continuous culture. Journal of General Microbiology 107, 131137.

Kaspar, H. F. \& Tiedje, J. M. (1980). Response of electron-capture detector to hydrogen, oxygen, nitrogen, carbon dioxide, nitric oxide and nitrous oxide. Journal of Chromatography 193, 142-147.

Kennedy, I. R., Rigaud, J. \& Trinchant, J. C. (1975). Nitrate reductase from bacteroids of Rhizobium japonicum: Enzyme characteristics and possible interaction with nitrogen fixation. Biochimica et biophysica acta 397, 24-35.

KNowles, R. (1982). Denitrification. Microbiological Reviews 46, 43-70.

Manhart, J. R. \& Wong, P. P. (1980). Nitrate effect on nitrogen fixation (acetylene reduction) activities of legume root nodules induced by rhizobia with varied nitrate reductase activities. Plant Physiology 65, 502-505.

Mozen, M. M. \& Burris, R. H. (1954). The incorporation of ${ }^{15} \mathrm{~N}$-labelled nitrous oxide by nitrogen fixing agents. Biochimica et biophysica acta 14, 577-578.

Murphy, S. G. \& ElKan, G. H. (1965). Nitrogen metabolism of some strains of Rhizobium japonicum having different nodulating capacities. Canadian Journal of Microbiology 11, 1039-1041.

Ohyama, T. \& Kumazawa, K. (1979). Assimilation and transport of nitrogenous compounds originated from ${ }^{15} \mathrm{~N}_{2}$ fixation and ${ }^{15} \mathrm{NO}_{3}-$ absorption. Soil Science and Plant Nutrition 25, 9-19.

PATE, J. S. (1977). Nodulation and nitrogen metabolism. In The Physiology of the Garden Pea, pp. 349383. Edited by J. F. Sutcliffe \& J. S. Pate. London: Academic Press.

PAul, E. A. \& Victoria, R. L. (1978). Nitrogen transfers between the soil and atmosphere. In Environmental Biogeochemistry and Geomicrobiology, volume 2, The Terrestrial Environment, pp. 525-542. Edited by W. E. Krumbein. Michigan: Ann Arbor Science.

Payne, W. J. (1981). Denitrification. New York: John Wiley.

PICCI, G. \& LePIDI, A. A. (1967). Alcuni aspetti della riduzione dei nitrati a nitriti ad opera di Rhizobium leguminosarum Frank. L'Agricoltura Italiana 66, 21 27.

Randall, D. D., Russell, W. J. \& Johnson, D. R. (1978). Nodule nitrate reductase as a source of reduced nitrogen in soybean, Glycine max. Physiologia plantarum 44, 325-328.

Rigaud, J., Bergersen, F. J., Turner, G. L. \& DANIEL, R. M. (1973). Nitrate dependent anaerobic acetylene-reduction and nitrogen-fixation by soybean bacteroids. Journal of General Microbiology 77 , 137-144.

SACKS, L. E. \& BARKER, H. A. (1949). The influence of 
oxygen on nitrate and nitrite reduction. Journal of Bacteriology 58, 11-22.

SiK, T., Kondorosi, A., Barabas, I. \& SVAB, Z. (1976). Nitrate reductase and effectiveness in Rhizobium. In Symposium on Nitrogen Fixation. vol. 2, pp. 374-382. Edited by W. E. Newton \& C. J. Nyman. Washington State University Press.

Smith, G. S., Edmonds, A. S. \& Middleton, K. R. (1980). Effects of chloramphenicol on growth, chemical composition and chlorophyll content of intact plants. New Phytologist 86, 181-189.

SMITH, K. A. (1980). A model of the extent of anaerobic zones in aggregated soils, and its potential application to estimates of denitrification. Journal of Soil Science 31, 263-277.

StreEter, J. G. (1982). Synthesis and accumulation of nitrite in soybean nodules supplied with nitrate. Plant Physiology 69, 1429-1434.

Trinchant, J. C. \& Rigaud, J. (1981). Acetylene reduction and respiration of bacteroids isolated from
French-beans receiving nitrate. Physiologia plantarum 53, 511-517.

Trinchant, J. C. \& Rigaud, J. (1982). Nitrite and nitric oxide as inhibitors of nitrogenase from soybean bacteroids. Applied and Environmental Microbiology 44, 1385-1388.

VANCE, C. P. \& Heichel, G. H. (1981). Nitrate assimilation during vegetative regrowth of alfalfa. Plant Physiology 68, 1052-1056.

Vasconcelos, L. De., Miller, L. \& Neyra, C. A. (1980). Free-living and symbiotic characteristics of chlorate-resistant mutants of Rhizobium japonicum. Canadian Journal of Microbiology 26, 338-342.

Zablotowicz, R. M. \& Focht, D. D. (1979). Denitrification, and anaerobic, nitrate-dependent acetylene reduction in cowpea rhizobium. Journal of General Microbiology 111, 445-448.

ZablotowiCZ, R. M., Eskew D. L. \& Focht, D. D. (1978). Denitrification in Rhizobium. Canadian Journal of Microbiology 24, 757-760. 